\title{
The Case for Collaboration to Foster Global Ocean Literacy
}

\author{
Meghan E. Marrero ${ }^{1,2 *}$, Diana L. Payne ${ }^{3}$ and Harry Breidahl ${ }^{4}$ \\ ${ }^{1}$ Center for STEM Education, Mercy College, Dobbs Ferry, NY, United States, ${ }^{2}$ National Marine Educators Association, \\ College Park, MD, United States, ${ }^{3}$ Connecticut Sea Grant, University of Connecticut Groton, Groton, CT, United States, \\ ${ }^{4}$ Nautilus Educational, Rosebud, VIC, Australia
}

The global ocean literacy movement began with a collaborative effort of like-minded individuals. This commentary highlights the role of marine education networks in the work of global ocean literacy, and discusses the importance of collaboration and action to promote a sustainable ocean future.

Keywords: ocean literacy, marine education, ocean education, marine science education, education networks

OPEN ACCESS

Edited by:

Rui Rosa,

University of Lisbon, Portugal

Reviewed by:

George I. Matsumoto,

Monterey Bay Aquarium Research Institute (MBARI), United States

Michael Kenneth Orbach,

Nicholas School of the Environment,

Duke University, United States

Tundi Agardy,

Sound Seas, United States

*Correspondence:

Meghan E. Marrero

mmarrero3@mercy.edu

Specialty section:

This article was submitted to

Global Change and the Future Ocean,

a section of the journal

Frontiers in Marine Science

Received: 07 February 2019

Accepted: 28 May 2019

Published: 21 June 2019

Citation:

Marrero ME, Payne DL and Breidahl H (2019) The Case for Collaboration to

Foster Global Ocean Literacy.

Front. Mar. Sci. 6:325.

doi: 10.3389/fmars.2019.00325
The development of the definition of ocean literacy-an understanding of the ocean's influence on you and your influence on the ocean-and the Essential Principles and Fundamental Concepts (Carley et al., 2013), was a collaborative effort of formal and informal educators, scientists, government professionals, and others interested in defining what everyone should know about the ocean (Cava et al., 2005). Many people involved in the initial effort were and are members of the US-based National Marine Educators Association (NMEA). This commentary highlights the role NMEA plays in fostering international ocean literacy networks, how the networks have supported ocean literacy, and a call for all organizations to work together to champion global ocean literacy for a sustainable future.

Founded in 1976, NMEA is a membership-based organization of more than 1,000 members from a wide range of backgrounds. A key benefit for members is the NMEA annual conference, which takes place in a different region of the US each summer. For decades, NMEA conferences have attracted ocean and coastal science and education professionals from around the world. The ocean literacy effort began in the United States as a way to effect change in the science education standards to better incorporate ocean science content into formal classroom education (Schoedinger et al., 2010). Since 2005, the focus expanded from improving ocean literacy in US schools to reaching multiple audiences (e.g., business professionals, scientists, policy makers, fishers) through various means (e.g., formal and informal education, Blue Growth strategies).

International participation in NMEA has inspired the formation of similar networks. A key component of this process is the open and collaborative mindset so prevalent at NMEA gatherings. While this mindset can be credited with inspiring international delegates, exposure to the concept of ocean literacy at NMEA conferences offered a framework for international networks.

One example of an international network inspired by NMEA is the founding of the International Pacific Marine Educators Network (IPMEN).The concept of IPMEN was conceived as the result of a 2 day meeting, the One Ocean Marine Forum (OOMF) on the Hawai' ian island of Maui in July 2005. OOMF originally formed as the result of an informal international meeting at the 2000 NMEA conference in Long Beach, California when a small group of marine educators from Australia joined a group of NMEA members in planning a Pacific Ocean forum that would follow the 2005 NMEA conference in Hawai' i.

The success of OOMF was a direct result of collaboration between NMEA and its Australian counterpart, the Marine Education Society of Australasia (MESA). As a result, IPMEN was formed at a second meeting in Hawai'i in February 2007 (Spalding 2008). Since 2008 IPMEN has met every 2 years at a different Pacific venue (www.ipmen.net). While IPMEN conferences focus on 
the development of a Pacific marine science education network and traditional knowledge, ocean literacy, and the continued support of NMEA has been critical.

Another result of the NMEA collaborative mindset is the establishment of the European Marine Science Education Association (EMSEA) http://www.emsea.eu/default.php. The inspiration for EMSEA was a direct result of the three founders meeting at the 2011 NMEA conference in Boston, Massachusetts. EMSEA now hosts annual conferences and was an instrumental partner in the European Union funded Sea Change and ResponSEAble https://www.responseable.eu/projects. Similarly, the Asia Marine Educators Association (AMEA) was established in 2015 as the founders attended the NMEA conference in Newport, Rhode Island. Networks have formed in other regions as well, including Canada, the Mediterranean, and Africa. NMEA and NMEA members have played a role in the development of these organizations.

Although strong national and regional networks exist, the critical question is, "How can all networks effectively collaborate to preserve our one global ocean?" Of course, there are many elements to consider related to ocean literacy, including ensuring ocean literacy efforts are culturally relevant and listening to the voices of diverse groups in the different regions. We can build upon successful models. For example, the EU SeaChange Project (http://www.seachangeproject.eu/) brought together 17 institutions from nine countries. Sea Change sought to improve citizens' ocean literacy to take "direct and sustainable action toward a healthy ocean, healthy communities and ultimately a healthy planet" (European Commission, 2011). In December 2017, UNESCO hosted the "Ocean Literacy for All”

\section{REFERENCES}

Carley, S., Chen, R., Halversen, C., Jacobson, M., Livingston, C., Matsumoto, G., et al. (2013). Ocean Literacy: The Essential Principles and Fundamental Concepts of Ocean Sciences for Learners of All Ages. Available online at: http://www. coexploration.org/oceanliteracy/documents/OceanLitChart.pdf

Cava, F., Schoedinger, S., Strang, C., and Tuddenham, P. (2005). Science Content and Standards for Ocean Literacy: A Report on Ocean Literacy. Available online at: http://www.cosee-se.org/files/coseeca/OLit04-05FinalReport.pdf (Retrieved 30, September 2018)

European Commission (2011). A Lesson in Ocean Literacy. Available online at: https://ec.europa.eu/programmes/horizon2020/en/news/lesson-ocean-literacy (Retrieved 10, December 2018)

Schoedinger, S., Tran, L. U., and Whitley, L. (2010). From the principles to the scope and sequence: a brief history
International conference. The event brought together scientists, educators, politicians, and others from 34 countries and four continents to discuss the importance of ocean literacy for different sectors and to share ideas to advance ocean literacy worldwide. A key element of this gathering was the financial support for attendees from developing nations, including South Asia, Africa, and South America.

The authors implore all ocean literacy networks work together in pursuit of three Ps: People, Products, and Partnerships, which the organizations featured above exemplify. Ocean literacy is a foundational element of these networks, and face-to-face meetings have been critical to advance this work. For instance, IPMEN, EMSEA, and AMEA hold regionally-based conferences on an annual or biennial basis. Furthermore, working groups are planning the joint NMEA 2020 and IPMEN 2020 conferences to be held in Honolulu, Hawai' i. The greatest challenge, however, is to develop stronger, more consistent, and more inclusive ways to communicate and share resources to develop products and enhance mutually beneficial partnerships. We recognize a truly ocean literate person not only understands ocean science content, but can also effectively communicate about the ocean and make informed and responsible decisions regarding the ocean and its resources. With this ambitious goal in mind, together we can advance global ocean literacy. The future of our ocean planet depends upon it.

\section{AUTHOR CONTRIBUTIONS}

All authors listed have made a substantial, direct and intellectual contribution to the work, and approved it for publication.

$$
\begin{aligned}
& \text { of the ocean literacy campaign. NMEA Special Rep. } \\
& 3,3-7 \text {. }
\end{aligned}
$$

Conflict of Interest Statement: The authors declare that the research was conducted in the absence of any commercial or financial relationships that could be construed as a potential conflict of interest.

Copyright (c) 2019 Marrero, Payne and Breidahl. This is an open-access article distributed under the terms of the Creative Commons Attribution License (CC BY). The use, distribution or reproduction in other forums is permitted, provided the original author(s) and the copyright owner(s) are credited and that the original publication in this journal is cited, in accordance with accepted academic practice. No use, distribution or reproduction is permitted which does not comply with these terms. 